\title{
Vegetal non-timber forest products in Cameroon, contri- bution to the national economy
}

\author{
A. AWONO ${ }^{1,2}$, R. EBA'A ATYl ${ }^{3}$, D. FOUNDJEM-TITA ${ }^{4}$ and P. LEVANG ${ }^{2,3}$ \\ ${ }^{1}$ University of Paul-Valéry, UMR-GRED, IRD, 34090 Montpellier, 30, Rue Suzanne Valadon, France \\ ${ }^{2}$ UMR GRED, IRD - 911 av. Agropolis, P.O. Box: 64501, 34394 Montpellier cedex 5, France \\ ${ }^{3}$ Center for International Forestry Research (CIFOR), P.O. Box 2008, Messa, Cameroon \\ ${ }^{4}$ World Agroforestry Centre (ICRAF), P.O Box 16317 Yaoundé, Cameroon
}

Emails: abdonawono@gmail.com; r.atyi@cgiar.org; d.foundjem@cgiar.org and p.levang@cgiar.org

\begin{abstract}
SUMMARY
This paper analyses the contribution of some non-timber forest products (NTFPs) to the economy of Cameroon through the lens of livelihoods, food security, employment and financial values. Specifically, the work aims at determining the income generated from vegetal NTFPs sales, the value of self-consumption and the number of jobs provided, in order to assess the contribution of NTFPs to the national economy. A combination of literature review and in-depth data collated by CIFOR from households and markets for different periods corresponding to specific NTFP funded projects in Cameroon was used. The results show that NTFPs constitute a regular source of income (even though not the most important) for rural households due to their diversity. About $38 \%$ of vegetal NTFPs are used as food and the annual economic value for 16 of them is estimated at 32 billion XAF (64.7 million USD). Their value added is estimated at 6.4 billion XAF (13 million USD) representing $0.2 \%$ of the GDP of the country with at least 283,000 people involved.
\end{abstract}

Keywords: livelihoods, NTFPs, national economy, income and employment

\section{Produits forestiers non-ligneux d'origine végétale au Cameroun, contribution à l'économie nationale}

\section{A. AWONO, R. EBA'A ATYI, D. FOUNDJEM-TITA et P. LEVANG}

Cet article analyse la contribution de quelques produits forestiers non ligneux (PFNL) à l'économie nationale camerounaise en matière de revenus, sécurité alimentaire, emploi et de valeur financière. L'étude s'attache à déterminer plus précisément les revenus générés par la vente de PFNL végétaux, la valeur de l'autoconsommation et le nombre d'emplois créés, afin d'évaluer la contribution des PFNL à l'économie nationale. L'étude s'appuie sur une revue de la littérature et des données compilées par le CIFOR à l'occasion d'enquêtes de ménages et de suivis de marchés concernant des PFNL ayant fait l'objet de projets de recherche. Les résultats montrent que les PFNL constituent une source régulière de revenus (sans être la plus importante) pour les ménages ruraux en raison de leur diversité. Environ 38\% des PFNL végétaux sont autoconsommés et la valeur économique annuelle de 16 d'entre eux est estimée à 32 milliards de francs CFA (64,7 millions de dollars US). Leur valeur ajoutée est évaluée à 6,4 milliards de francs CFA (13 millions de dollars US) représentant ainsi 0,2\% du produit intérieur brut du pays, et employant 283000 personnes.

\section{Productos forestales no maderables de origén vegetal en Camerún, contribución a la economía nacional.}

\section{A. AWONO, R. EBA'A ATYI, D. FOUNDJEM-TITA y P. LEVANG}

Analizamos en este trabajo la contribución de algunos productos forestales no maderables (PFNM) a la economía de Camerún desde la perspectiva de los medios de subsistencia, la seguridad alimentaria, los empleos y los valores financieros. En concreto, el objetivo del trabajo es determinar los ingresos generados por la venta de los PFNM, el valor del autoconsumo y el número de puestos de trabajo proporcionados, para evaluar la contribución de los PFNM a la economía nacional. Utilizamos una combinación de la revisión de la literatura y datos recopilados en profundidad por CIFOR de los hogares y mercados para diferentes períodos correspondientes a proyectos de específicos PFNM financiados en Camerún. Los resultados muestran que los PFNM constituyen una fuente regular de ingresos (aunque no la más importante) para los hogares rurales debido a su diversidad. Alrededor del 38\% de los PFNM vegetales se utilizan como alimento y el valor económico anual de 16 de ellos se estima en 32 mil millones de francos CFA (64,7 millones de dólares). Su valor añadido se estima en 6,4 mil millones de francos CFA (13 millones de dólares), lo que representa el 0,2\% del PIB del país con al menos 283000 personas involucradas. 


\section{INTRODUCTION}

Tropical forest goods and services are often surrounded by emerging markets linking remote communities with major urban centers, nationally and internationally (Nkem et al. 2010). FAO (2010a) estimated that the value of NTFPs extracted from forests worldwide amounted to US\$18.5 billion in 2005). In addition, it is widely acknowledged that non-timber forest products (NTFPs) serve as safety nets for forest communities (Arnold 2002). However there is an information gap from many countries about the economic value of NTFPs because the true value of subsistence use is often rarely captured. Most of the time, only the quantities of NTFPs sold are taken into account and most employments in the forestry sector occur in the informal sector (Schreckenberg et al. 2006, FAO 2010a). The term economic value used in this paper covers the value of both sold and self-consumed NTFPs.

Cameroon has a population of about 20 million inhabitants consisting of approximately 200 ethnic groups of which, more than $45 \%$ live in rural areas (World Bank 2012). It is widely acknowledged that forests and NTFPs play a key role in the daily life of millions of people living in rural areas in Cameroon (Awono et al. 2002a, Cosyns et al. 2011, Ndoye et al. 1997/98, Schreckenberg 2006). For these people, the collection of forest products constitutes an important source of food and of cash. Foundjem (2013) reported that in 2011, 70 traders who sold four NTFPs (Irvingia sp., Ricinodendron heudelotii, Gnetum spp., Cola acuminata) after they travelled from the production villages to the market, received a total of 1.7 billion XAF, of which they have spent a total of 212.5 million XAF as rental permits from the privileged owners and unofficial taxes that ended up in the pockets of corrupt government officials. These same traders supported other expenses such as transportation, handling, market taxes, representing about $13 \%$ of the gross sales. Further analysis by the same author showed that, of the 212.5 million of charge that has flowed into the economy, 54\% went to the private pockets of police and the forest officers, 34\% to permit owners and 9\% (about 9 million XAF) to the national treasury under tax generation. Similarly, Ndoye and Awono (2010) estimated informal taxes for a car transporting 1.5 ton of Gnetum spp. leaves from the Centre region to Idenau in the Southwest region (about $400 \mathrm{~km}$ ) to be about USD 530. The same authors revealed that every Idenau market day (3 times a week) police controls-including gendarmes, forest guards and customs officers- were doubled along the defined itinerary for grabbing non official taxations or briberies from customers.

According to local people, those products may reflect better the expected conservation efforts on forests (Djeukam 2007). Since the 1980s, scientists like de Beer and McDermott (1989) and Peters (1989) argued that NTFPs have a high potential for forest conservation and poverty alleviation. It was argued that the usefulness of these products to the local people would encourage them to sustainably manage the forests resources.
Although the literature has generally found that NTFPs can diminish hunger and provide employment for local people, there are actually few statistics to build a strong case for NTFPs in Cameroon and many other countries in the world (FAO 2010). In fact, national level data is often limited to some export species and sometimes to some endangered species. Yet such information is crucial at the policy level in order to encourage decision makers to continue to support sustainable development and trade in such products (Belcher 2005, FAO 2010a, Tahir et al. 2004). Despite its policy relevance, and the existence of many studies describing the value chains of NTFPs, assessing their economic value including both the quantities of NTFPS sold and self-consumed at the national level is not always an easy task. One reason is that most studies analyzing such products are project and/or region specific, in which case having a general picture at the national level is often difficult.

The objective of this paper is to add to the literature by analysing the contribution of some selected NTFPS to the economy of Cameroon. As part of the Special Issue, this paper will restrict the analysis to vegetal NTFPs while other papers will target different types of NTFPs. Usually, the value of NTFPs is an indicator of the contribution of the subsector to national economies (FAO 2010a). The contribution to national economy in this case is assessed by paying attention to two group of variables i) the financial value of some selected NTFPs that are collected and sold or self-consumed; and ii) some social indicators-the contribution of the selected NTFPs to poverty alleviation especially as NTFPs are often collected by the poor (Schreckenberg et al. 2006); contribution to livelihoods specifically to food security (consumption) and to employment. Cameroon is one of the most diverse countries in Africa both in terms of biodiversity and population (Letouzey 1968). Located in Central Africa, the country counts more than 8,500 plant species (Betti 2007) out of which about 710 are currently used as NTFPs (Ingram 2014). However, only a few NTFPs, for which data can be found, will be analysed in this study.

\section{MATERIALS AND METHODS}

This study addresses NTFPs from different regions in Cameroon with particular emphasis on the humid forest zone because it is the origin of most NTFPs traded in the country. Furthermore, the humid forest zone is one of the few regions where most studies have been conducted on NTFPs and for which relevant data can be found. The focus is put on vegetal NTFPs because other chapters in this edition will address the other types of NTFPs.

The results presented in this paper are derived both from literature review and primary data. The literature consulted includes project reports and other scientific literature targeting producers' livelihoods, including (1) Forest Research Program initiative financed by Department for International Development (DFID), involving the World Agroforestry Centre (ICRAF), Institute of Agronomic Research for Development (IRAD), local NGOs and Center for International 
Forestry Research (CIFOR) (1999-2004), (2) Farmer enterprise development project funded by the Belgian Development Cooperation implemented by ICRAF, Central Africa Regional Program for the Environment (CARPE), farmer organisations and CIFOR (2003-2007), and (3) NTFPs project funded by European commission (EC) including the Food and Agricultural Organization of the United nations (FAO), the Netherlands Development organization (SNV) and CIFOR, under Central African Forests Commission (COMIFAC) (2007-2011). In these projects household questionnaires and focus group discussions were used to feed socio-economic analyses. Information gathered from the literature includes quantities of vegetal NTFPs produced, self-consumed and sold at the farm level. Furthermore, information about potential jobs provided to different actors along the NTFP value chains is also reported. Overall the information generated from these different initiatives concerned a total of 16 NTFPs (Tables 1, 2). The market surveys included twelve markets specialized in the sales of NTFPs (Mfoundi, Mbalmayo, Ebolowa, Kye-Ossi, Abang-Minko, AbongMbang, Newbell, Limbe, Mile four, Ekondo-Titi, MakeneCentre and Makene-Est). The markets were selected based on a cumulative set of criteria: (1) effective sales of NTFPs, (2) regional coverage of major supply regions in the humid forest zones (3) accessibility to those markets by traders and researchers (Ruiz-Perez et al. 2000). About 200 permanent traders were interviewed on market transactions including NTFPs sold, origin, prices, costs, etc.

Data from these two sources were compiled to meet the objectives of the current studies. However we acknowledge information gaps related to the absence of systematic data collection procedures from the various literatures consulted. These gaps are however not specific to Cameroon and to the NTFPs subsector. Several studies have highlighted current forest related data collection deficiencies and information gaps in both developed and developing countries despite the existence of a large number of studies that attempt to quantify and estimate the value of forest products including NTFPs (FAO 2010a, Ingram and Bongers 2009). Despite these shortcomings, the latter authors recommend continuous efforts to demonstrate the value and contribution of NTFPs to poverty, employment and livelihoods.

As a consequence of the strong diversity and the dispersed nature of the data available on NTFPs, we concentrated first on those most studied by research institutions and that are widely commercialized within the country. The second group of NTFPs (table 2) stems from the list of Special Products, issued by the Ministry of Forestry and Wildlife (MINFOF). Thus, the economic value of the NTFPs considered in this paper, are presented from two viewpoints: (1) financial value of the quantities of NTFPs sold with and without official permits, and (2) the financial value of self-consumption by producers for both categories of NTFPs. Here after we use the term producers instead of collectors or harvesters because most of the NTFPs concerned by this article are processed to certain extend.

The financial value (market value) was assessed by looking first at the annual sales of the 16 selected NTFPs that have been divided into two categories: (i) sales without permits including 9 products, and (ii) sales with permits for 7 products (Table 2). These 7 products are those found in the 2012 list of products attributed by the government via the body responsible for Cameroon's forests. It may be important to mention that since the 1994 law, NTFPs trade is subject to obtaining a permit (clarifying the species and the volumes allowed). The permit is supposed to qualify the license holder to the forestry profession. This means that all NTFPs marketed in the absence of these documents fall under the informal or illegal domain. However, as mentioned earlier, a majority of the activities in the NTFP sector occur in the informal domain. This means that while quotas for the seven products were used in the analysis, data on informal transaction of the seven selected species were also captured.

To determine the annual financial values of NTFPs that are self-consumed by producers/collectors, in each case (Tables 1 and 2), annual sale values (columns d) from annual sold quantities (columns b) were projected on the proportion obtained (column e) from additional interviews conducted with 38 actors involved in the NTFPs' value chain including NTFPs Trade Union (4), MINFOF (8), Agriculture and scientific research, through the Institute for Research on Agriculture for Development (20) and Commerce (6). Finally each product was evaluated in its context to obtain a reliable proportion of self-consumption doubled with informal sales in small markets, which were not captured in our market analysis (Tables 1 and 2). Results obtained are explained not only by looking at the contribution of the NTFPs to various actors in the chain (producers, traders and State) but also by presenting the social importance of NTFPs (employment and food security).

Employment means different things to different people. In a broad sense the term encompasses all types of activities including the state of being employed, the occupation for which you are paid or an activity that occupies a person's time. In this paper employment relates to how many and what kinds of people make a living engaging in NTFPs related activities. It also includes income from employment in the NTFP sector that may be formal or informal.

As defined during the World food summit of 1996, food security exists when all people at all times have access to sufficient, safe, nutritious food to maintain a healthy and active life (FAO 1996). Commonly, the concept of food security includes both physical and economic access to food that meets people's dietary needs as well as their food preferences. The contribution of NTFPs to food and nutritional security is thus assessed in these terms.

\section{RESULTS}

The results have been structured in four sections including: (1) description of NTFPs production sites and value chain, (ii) sales value in financial terms of the 16 NTFPs differentiating sales without permit and sales with permits because we know that not all NTFP sold are under permits, (iii) Social importance of NTFP in terms of employment and livelihoods and 
(iv) the revenues generated by the Government from NTFPs exploitation in Cameroon.

\section{Description of NTFPs production sites and market chains in Cameroon}

Though we know that most of these products are derived from the humid forest zone of Cameroon (Awono et al. 2002a, Ndoye et al. 1999), they are not necessarily harvested from forest lands. For Gnetum spp. for instance, more than $76 \%$ of producers reported that they collected the product from fallow lands (Eyebe et al. 2004); for Dacryodes edulis, more than 95\% comes from non-forested lands, cocoa plantations and fallows ranking first (Awono et al. 2010). On the reverse, others like Irvingia sp. trees are mainly found in secondary and primary forests. An analysis of the potential of NTFPs in cocoa agroforests at Nkoemvon in the South region of Cameroon revealed that on a surface of 10 ha, only nine Irvingia sp. trunks were observed, that is less than one trunk per hectare. Similar results obtained on Irvingia sp. by Van Dijk (1999) in the Bipindi and Akom II areas, showed a low density of this species in anthropogenic formations because most of cocoa agroforests were created when the exploitation of these species was still negligible. They were primarily used as food and eventually in traditional pharmacopoeia (Awono et al. 2002a). This situation reflects the scarcity of NTFPs with economic value in the accessible zones for producers, which often turns into harvesting conflicts (Awono et al. 2009a). Apart from Arabic Gum that is well-known, the northern part of Cameroon is not well represented in terms of NTFPs production.

Producers sell their NTFPs to middlemen, semiwholesalers or wholesalers from surrounding cities linked to retailers or exporters. In some cases, exporters get their supplies directly from producers, especially when the season is running to the end. Middlemen do not own capital but act on behalf of wholesalers. They are especially linked by trust. After having agreed on the unit price with their counterpart, they try to maximize their profit in the field by offering relatively lower buying prices to producers before getting compensated by their boss later on. As such, their level of profit depends on their ability to negotiate on the ground. On the contrary, semi-wholesalers have their seed capital and can be linked both to retailers or wholesalers (Awono et al. 2010). This category of traders is essentially spontaneous and generally consists of people with other activities (civil servants for instance), who join the market when there are intensive activities for well-known NTFPs such as Irvingia sp. or Ricinodendron heudelotii (Awono et al. 2009a). Some Cameroonian wholesalers have established business relationships with wholesalers from other countries like Nigeria, Gabon or Equatorial Guinea. Once confidence has been established, external wholesalers can put more funds in the business, depending on the level of confidence. Retailers constitute the last step in direct contact with consumers. Most of the time they are stable in the market and pay communal taxes per day (100 XAF) no matter the number of products sold, as they usually sell several products at once (Awono et al. 2009a).

\section{Economic value of NTFPs studied in Cameroon}

It should be acknowledged that no single good has a fixed value. However, the amount of labor needed to produce a good can be considered to be its value but not its economic value. In a free economy like in Cameroon, the economic value of a good is the maximum amount a consumer is willing to pay or has paid for it. Thus, the economic value of NTFPs considered in this paper is presented from two viewpoints: (1) Financial value of the quantities of NTFPs sold with and without official permits, and (2) the financial value of NTFPs based on the quantities that are self-consumed.

Estimating the financial value of the quantities of NTFPs sold with and without official permits

The estimated sales value of the 9 selected NTFPs mostly sold without official permit in the markets studied is about 9.6 billion XAF (19 million USD) (Table 1). The sales value from Dacryodes edulis appears to be the most important, reaching 4.4 billion XAF (8.8 million USD). Douala (Littoral), Yaoundé and Makenene (Center) are the most important markets. The second NTFP that needs greater attention is Irvingia sp. with a total sale value of 4 billion XAF ( 8 million USD) per year. The highest transaction volumes of Irvingia

FIGURE 1 NTFPs Market value chain in Cameroon

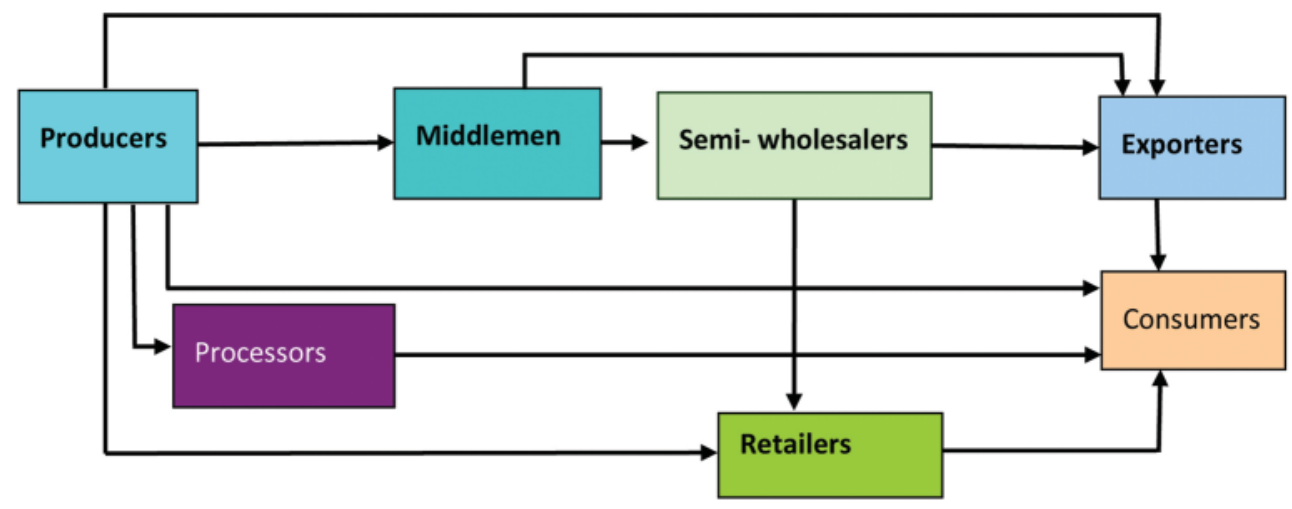


TABLE 1 Annual sale value of NTFPs studied, sold without permit

\begin{tabular}{|c|c|c|c|c|c|c|c|}
\hline a. NTFPs & $\begin{array}{l}\text { b. Total } \\
\text { quantities } \\
\text { sold per } \\
\text { year } \\
\text { (Tons) }\end{array}$ & $\begin{array}{c}\text { c. NTFPs } \\
\text { average } \\
\text { consumer } \\
\text { price } \\
(\mathrm{XAF} / \mathrm{kg})\end{array}$ & $\begin{array}{l}\text { d. Annual sale } \\
\text { values from } \\
\text { sold quantities } \\
(X \text { million } X A F)\end{array}$ & $\begin{array}{l}\text { e. Rate of auto } \\
\text { consumption + } \\
\text { non studied } \\
\text { market } \\
\text { percentage }\end{array}$ & $\begin{array}{l}\text { f. Financial } \\
\text { Value of auto } \\
\text { consumption }+ \\
\text { estimates from } \\
\text { non-studied } \\
\text { market } \\
(X \text { million } X A F) \\
(\mathbf{d} \mathbf{x} \text { e) }\end{array}$ & $\begin{array}{l}\text { g. Cumulative } \\
\text { annual value } \\
\text { of targeted } \\
\text { NTFPs } \\
(X \text { million } X A F) \\
\\
(\mathbf{d}+\mathbf{f})\end{array}$ & h. Data source \\
\hline Irvingia sp. & 2700 & 1500 & 4,050 & 0.6 & 2430 & 6480 & \multirow{8}{*}{$\begin{array}{l}\text { Data collected by } \\
\text { CIFOR within the FRP } \\
\text { (1999-2004), FED } \\
(2003-2007) \text { and EC } \\
\text { (2007-2011) projects } \\
\text { completed by inter- } \\
\text { views with the value } \\
\text { chain actors including } \\
\text { officials from } \\
\text { ministries in } 2014 \text { as } \\
\text { indicated in the method } \\
\text { section }\end{array}$} \\
\hline $\begin{array}{l}\text { Tetrapleura } \\
\text { tetraptera }\end{array}$ & 207 & 300 & 62 & 0.5 & 31 & 93 & \\
\hline Cola nitida & 359 & 600 & 215 & 1 & 215 & 430.8 & \\
\hline Cola acuminata & 134 & 1000 & 134 & 2 & 268 & 402 & \\
\hline Garcinia kola & 50 & 2500 & 125 & 2 & 250 & 375 & \\
\hline Garcinia lucida & 85 & 1500 & 128 & 0.2 & 25.5 & 153 & \\
\hline $\begin{array}{l}\text { Baillonella } \\
\text { toxisperma (Oil) }\end{array}$ & 4 & 1500 & 6 & 0.8 & 4.8 & 10.8 & \\
\hline $\begin{array}{l}\text { Ricinodendron } \\
\text { heudelotii }\end{array}$ & 182 & 2000 & 364 & 2 & 728 & 1092 & \\
\hline $\begin{array}{l}\text { Dacryodes } \\
\text { edulis }\end{array}$ & 11000 & 400 & 4400 & 0.5 & 2200 & 6600 & $\begin{array}{l}\text { Awono et al. } 2002 \\
+ \text { Ayuk et al. (1999) }\end{array}$ \\
\hline Total & - & - & 9664 & - & 6153 & 15637 & - \\
\hline
\end{tabular}

sp. are registered between Cameroon and some neighboring countries, of which 2,400 tons are oriented towards Nigeria. The average price of a $\mathrm{kg}$ of Irvingia sp. kernels amounts to 1,500 XAF. Ebolowa and Mbalmayo markets are playing a key role in transferring Irvingia sp. to Nigeria and Equatorial Guinea, generating respectively $71 \%$ and $19.5 \%$ of the total volumes. This is due to the proximity of these cities with the main production zones in the Center and South regions (Awono et al. 2009a).

The total annual sale values of NTFPs sold under the permit system was estimated to be 8.3 billion XAF (16.7 million USD) (Table 2). Most NTFPs under this category are medicinal species, Cameroon providing the industrial firms with the raw material. Prunus africana is the champion on the list with very little quantities (less than $1 \%$ ) used locally for malaria and other diseases. Used as an alternative medicine in treating benign prostatic hyperplasia, Prunus africana is protected in appendix II of CITES. Cameroon reduced the exported quantities after the country was banned from exports to European Union markets. Therefore, 674 tons were allocated in 2012, generating about 700 million XAF (1.4 million USD). On the other hand, Gnetum spp. has caught the government's attention because of substantial demands from the market, creating some doubts on the sustainability of the harvestings. From the 4,400 tons received by economic operators, our estimate of the annual sales of Gnetum spp. is about 5.7 billion XAF (11.4 million USD). Overall, the total annual sale value of the 16 NTFPs from the two categories (permit and non-permit systems) reported in this paper is approximately 18 billion XAF (36 million USD).

\section{Financial values of NTFPs based on quantities that are self-consumed}

The economic value is the maximum amount of money a buyer is willing and able to pay for the item. This value in terms of vegetal NTFPs mostly studied in Cameroon has generally been underestimated as self-consumption has usually not been incorporated (Ingram and Bongers 2009, Ingram 2012). The real issue is that there are conflicting data about the proportion of NTFPs that are self-consumed by collectors and that which they sell. For instance, while van Dijk (1999) suggests that only $10 \%$ of the production of Dacroydes edulis is marketed, Ayuk et al. (1999) find that just over $40 \%$ of annual production of the same product is sold. The discussions organised with some officials from the ministries of agriculture, forestry and scientific research through IRAD led to the conclusion that approximately half of the national production is sold. The figure from van Dijk was probably underestimated for the year concerned as the data was likely more focused on the South region of Cameroon. In another study implemented in Lekié division, Nnama et al. (2012) found that $24 \%$ of Gnetum spp. harvested is consumed within the producer households, $15 \%$ is given to family members and friends and the remainder $(61 \%)$ is sold with a small portion spoiled. Similarly Awono et al. (2009a 2010) found that the highest quantity $(58 \%)$ of Irvingia sp. kernels 
TABLE 2 Financial values of NTFPs governed by the permit system

\begin{tabular}{|c|c|c|c|c|c|c|c|}
\hline a. NTFPs & $\begin{array}{l}\text { b. Annual } \\
\text { quotas } \\
\text { from } 2012 \\
\text { attributions } \\
\text { (Tons) }\end{array}$ & $\begin{array}{l}\text { c. Average } \\
\text { consumer } \\
\text { unitprice } \\
(\mathrm{XAF} / \mathrm{kg})\end{array}$ & $\begin{array}{l}\text { d. Annual sale } \\
\text { values from } \\
\text { quotas attributed } \\
\text { by government } \\
(X \text { million } X A F) \\
\text { (b x c) }\end{array}$ & $\begin{array}{c}\text { e. Rate** } \\
\text { auto } \\
\text { consumption } \\
\text { + domestic } \\
\text { markets } * * *\end{array}$ & $\begin{array}{c}\text { f. Annual } \\
\text { financial value } \\
\text { from auto } \\
\text { consumption or } \\
\text { domestic markets } \\
(X \text { million } X A F) \\
(\mathbf{d} \mathbf{x} \mathbf{e})\end{array}$ & $\begin{array}{l}\text { g.Cumulative } \\
\text { annual value of } \\
\text { targeted } \\
\text { NTFPs } \\
(X \text { million } \\
X A F) \\
(\mathbf{d}+\mathbf{f}) \\
\end{array}$ & $\begin{array}{l}\text { h. Source of auto } \\
\text { consumption }+ \\
\text { domestic markets } \\
\text { estimates }\end{array}$ \\
\hline Funtumia africana & 7000 & 200 & 1400 & 1 & 1400 & 2800 & \multirow{3}{*}{$\begin{array}{l}\text { Focus group } \\
\text { discussions with } \\
\text { villagers, exporters } \\
\text { and syndicates of } \\
\text { NTFPs + data from } \\
\text { COMCAM }\end{array}$} \\
\hline Rauvolfia vomitoria & 6 & 450 & 3 & 1 & 3 & 5 & \\
\hline $\begin{array}{l}\text { Pausinystalia } \\
\text { johimbe }\end{array}$ & 655 & 650 & 426 & 1 & 426 & 852 & \\
\hline Gum arabic & 116 & 455 & 53 & 9 & 475 & 528 & $\begin{array}{l}\text { Quotas 2012+ } \\
\text { Njomaha, 2008 }\end{array}$ \\
\hline Gnetum spp. & 4400 & 1300 & 5720 & 1 & 5720 & 11440 & $\begin{array}{l}\text { Awono et al. } 2002 \mathrm{a} \\
\text { Ndumbe } \text { et al. } 2009\end{array}$ \\
\hline Rattan & 201 & 300 & 60 & 6 & 362 & 422 & Defo, 2004 \\
\hline Prunus africana* & 674 & 1050 & 708 & 0.01 & 7 & 715 & Awono et al. 2009b \\
\hline Total & - & - & 8370 & - & 8393 & 16762 & - \\
\hline
\end{tabular}

* Prunus africana exports were reduced after the band (2007) and readmission (2011) of exports from Cameroon to EU countries. Quotas attributed are now based on the national Prunus africana management plan proposed by CIFOR in 2009. The unit price here is the FOB price that includes the different costs.

** Hypothesis of the proportion of self-consumption compared to the annual quotas

*** The term "domestic market" here means transactions taking place in internal markets as the target products are particularly exported.

produced in the humid forest zone goes to the market while $37 \%$ is directly consumed in producers' households or through gifts.

Analysing the importance of NTFPs in 5 sites in South and East regions, Lescuyer (2010) found that NTFPs had been collected by the large majority of studied households (81$100 \%$ of a total sample of $\mathrm{xx}$ ) but in some villages, especially those close to urban markets like Bipindi, the proportion of the NTFPs sold is low (29\%) while in others a hundred percent of households sell their collection. In a similar study, most of the time, households produce NTFPs both for self-consumption and income generation. For Ricinodendron heudelotii for instance, $42 \%$ of it producers do so only for sale and $58 \%$ collect it for both the market and domestic consumption. On the other hand, Nnama et al. (2012) showed that up to $49 \%$ of Gnetum spp. leaves harvested in the Center region are shared between household consumption, family members and friends out of the village. In a similar study, Awono et al. (2009a) found that about $40 \%$ of the production of Irvingia $\mathrm{sp}$. is used within the producer's household, family members and relatives. In any case, while the market plays a key role in NTFPs use, self-consumption remains determining in rural areas. As a result, self-consumption led to a total of 6.1 billion XAF (12.3 million USD) for the 9 NTFPs mostly sold without official permits considered in this paper (Table 1).

For the 7 NTFPs under the quota system, relatively little has been written on estimates of sales on the domestic market or of the quantities used in producers' households. This is very important because any policy change on forest and trade cannot be envisaged by decision-makers without having some statistics on how this sector can support the national economy. For some products, the income generated will below, but they are used within the households in terms of food or medicine. In this case the economic value of such products tends to be more important due to self-consumption. Thus, beyond the financial values of NTFP based on the quantities that are sold, our goal is to highlight the contribution of the proportion of NTFPs that are self-consumed, to the national economy. The self-consumption and domestic market for the 7 NTFPs targeted reaches a total of 8.3 billion XAF (16.7 million USD) per year (Table 2).As a result, including both NTFPs sold under the permit system and NTFPs sold without permit we reach a cumulative average financial value of 14.5 billion XAF (29million USD) for self-consumption for one year.

\section{Combined financial value of the selected NTFPs marketed and self-consumed}

Ultimately the combined economic value derived from both marketed and consumed NTFPs analysed in this paper has been estimated at 32.3 billion XAF equivalent to 64.7 million USD (Table 3 ). This figure represents about 0.2 percent of the Gross Domestic Product (GDP) in Cameroon. On the other hand with regard to the literature obtained, the market access cost was evaluated at $30 \%$ of the gross sales of the targeted NTFPs resulting in 6.4 billion XAF. Thus, by deducting the market access cost from the total financial value of the 16 
TABLE 3 Economic values of the 16 NTFPs analysed from the two categories

\begin{tabular}{lccccccc}
\hline & \multirow{2}{*}{$\begin{array}{c}\text { Number of } \\
\text { NTFPs }\end{array}$} & \multicolumn{2}{c}{ Market Value } & \multicolumn{2}{c}{$\begin{array}{c}\text { Value from self-consumption } \\
\text { and informal sector }\end{array}$} & \multicolumn{2}{c}{ Total } \\
\cline { 3 - 8 } & analysed & $\begin{array}{c}\text { XAF } \\
(X \text { million })\end{array}$ & $\begin{array}{c}\text { USD } \\
(X \text { million })\end{array}$ & $\begin{array}{c}\text { XAF } \\
(\text { X million })\end{array}$ & $\begin{array}{c}\text { USD } \\
(X \text { million })\end{array}$ & $\begin{array}{c}\text { XAF } \\
(X \text { million })\end{array}$ & $\begin{array}{c}\text { USD } \\
(X \text { million })\end{array}$ \\
\hline $\begin{array}{l}\text { NTFPs marketed } \\
\text { without permits }\end{array}$ & 9 & 8370 & 16.7 & 8393 & 16.7 & 16762 & 33.5 \\
\hline $\begin{array}{l}\text { NTFPs governed by } \\
\text { the quota system }\end{array}$ & 7 & 9664 & 19.3 & 6153 & 12.3 & 15637 & 31.2 \\
\hline Total & $\mathbf{1 6}$ & $\mathbf{1 8 ~ 0 3 4}$ & $\mathbf{3 6 . 0 6}$ & $\mathbf{1 4 ~ 5 4 6}$ & $\mathbf{2 9}$ & $\mathbf{3 2 ~ 3 9 9}$ & $\mathbf{6 4 . 7}$ \\
\hline
\end{tabular}

NTFPs, an estimate of 26 billion XAF (52 million USD) was obtained.

\section{The social importance of NTFPs in Cameroon}

NTFP as a source of jobs

It has been increasingly acknowledged that the NTFPs sector hides a great potential of employment in Cameroon (Awono et al. 2010, Ingram 2014, Ndoye et al. 1998) however, as in many other countries, having consolidated data on the magnitude of this contribution is a daunting task. In many families in rural areas, especially in the humid forest zone, after agriculture that comes largely ahead (Lescuyer 2010), NTFPs can be one of the main sources of income. In fact, the market chain of NTFPs involves thousands of people both at the farm level and in cities. One of the reasons has been the drastic drop of cocoa and coffee prices in the mid-1980s and the devaluation of the national currency in 1994. These economic factors pushed Cameroon's rural population to turn more to the forests for alternative sources of livelihood and nutrition.

Awono et al. (2013) reported that at least 283000 people in Cameroon work, at various degrees, in the value chain of NTFPs. These may be direct or indirect jobs. For example, in a study on NTFPs in a joint project with FAO and other actors, Awono et al. (2009a) found that these products generate the equivalent of 32,700 and 250,000 direct and indirect jobs respectively in Cameroon. From the analysis of the market chain of Gnetum spp. under the same project, Ingram (2012) calculated a total of 2550 people involved in Littoral and Southwest regions of Cameroon. You also have about 759 middlemen (working for semi-wholesalers or exporters) circulating in 18 villages from the two regions targeted by the study. In addition, there are about 179 traders (working with their own financial capital) buying Gnetum spp. directly from collectors. It was found that the monthly amount received by these traders is more than two times the minimum guaranteed wage in Cameroon(2 x 31,625 XAF) (Awono et al. 2009a). Similarly and although not yet developed, processed NTFPs generate additional income for households and tend to reduce the scarcity of supplies due to cyclic production of trees and the highly perishable nature of some of them. In addition, productions turn to be unpredictable in general. Some trees only produce every 3 years and when the product is available it must be processed quickly. Unfortunately, more than $95 \%$ of the production is sold in raw form. Yet, the development of this sector contributes to the emergence of many jobs.

NTFPs ensure food security to rural and urban population Food security is a relevant term through all types of edible products including NTFPs and agricultural products, especially for local people. NTFPs have been recognized as capable of meeting essential livelihoods aspirations, especially in rural areas. Beyond the market supply role, these products contribute directly to food security in households, especially when other activities like cocoa fail to generate enough cash. NTFPs then reinforce the living standard of rural people not necessarily by providing them with cash but by supporting their diet (Lescuyer 2010). These products contribute significantly to food security in Cameroon, especially during times when the food gap needs to be bridged. In three out of four villages in the Southwest region of Cameroon, most households reported a decrease in forest products consumption over the 12 months prior to the survey, because the household members travel far (average distance of 100 to 120 minutes) into the forest to harvest NTFPs, however all recognized that they all depend on NTFP for food (Awono et al. 2015). The same figure was obtained in the East and South regions (Awono et al. 2015). The same authors reported that 530 households interviewed in the same regions, 95\% indicated that some of the NTFPs they were used to are getting rare or have simply disappeared, worsening their food provision, especially for hunger gap periods. However, Van Noordwijk (2014) pointed out that some NTFPs are more easily stored and traded over long distances. These products have a greater chance to be developed if appreciated by consumers and available in the wild. Domestication could leverage the availability problem and improve their contribution both to food security and income generation for poor people. It is important to make sure that local people have interchangeable income sources along the year to cover the lack of food with purchased goods. Although local people will still get food from forest ecosystems and agriculture, the market economy is gradually modifying the past choices. From the same data collected in 520 households, $100 \%$ reported they were getting an important part of their food from the market, leading to the conclusion that there is an 
irrefutable correlation between income security and food security. Awono (2009a) reported that because Irvingia sp. is sold particularly before school resumes, $38 \%$ of its revenues are used for children education, $26 \%$ for various household daily needs and $18 \%$ in family health. Only $2 \%$ can be saved. This result shows that forest products contribute at least to two of the Millennium Development Goals (MDG) objectives, namely reducing extreme poverty and hunger (1) and ensuring primary education for all (2).

\section{How do NTFPs contribute to improve the revenue of producers/collectors?}

In Cameroon NTFP production is usually restricted to individuals, households or extended families. In some cases producers form common initiative groups limited to a maximum of 10 members (Awono et al. 2009b). Though the costs of NTFPs production lack in general, Awono et al. (2002b) found that far from being exploited by traders, producers of Dacryodes edulis receive $40 \%$ of the consumer price on average while the remaining amount is distributed among market access costs and traders' profit. In a similar study with traders, Ndoye et al. (1998) found that the average profit margin of traders was about $30 \%$ of the consumer price, which means that about $30 \%$ will be invested in market access costs including transport, handling, storage and communal tax.

In terms of NTFPs impact on household income, Ingram (2014) reported that $47 \%$ of the household economy in rural areas relies on NTFPs including fruits, leaves, barks, roots, etc., contributing about 561,000 XAF (1122 USD) per year. In the meantime, evaluating the contribution of Ricinodendron heudelotii to the household economy, Cosysn et al. (2011) found that half of the households' income generated from Ricinodendron heudelotii amounted to an average of 430,000 XAF (860 USD) at Akonolinga in 2010, while the remaining households receive between 15000 and 54000 XAF (from 30 to 108 USD). In another area of the humid forest zone, Tieguhong and Nkamgnia (2012) showed that the annual income of NTFPs in households around Lobéké National Park varied between 44,000 and 290,000 XAF (from 87.8 to 581.4 USD). In the Southwest region, Prunus africana producers around Mount Cameroon derive $70 \%$ of their annual income from this activity (Ndam 2004). As it can be seen, the revenues from NTFPs vary from one place to another and sometimes some NTFPs such as Ricinodendron heudelotii or Irvingia sp. have a great influence on the trend of NTFPs contribution to households in terms of income. One explanation may be the fluctuation of human expertise in terms of technical knowledge in producing demanded NTFPs. Another reason may be the lack of appropriate equipment extending the time and efforts to be devoted to the activities to deliver expected quantities. One hypothesis can be that those who get more return from NTFPs production are those who renounce to some of their household activities, and who specialize at the local level (Awono et al. 2002a). Another explanation may come from the fact that some areas are more degraded than others due to non-sustainable land use systems. The same author showed that most of the time the availability of NTFPs contrasts with the type of infrastructures. The accessibility would then influence the possibility of extraction of NTFPs as fewer traders are able to reach the areas where the roads are problematic, thus increasing the market access cost. In contrast, agriculture may not prosper in remote zones. In that context, forest conversion for agriculture will be reduced and NTFPs better protected (Awono et al. 2002a). For NTFPs generating revenues in households, Ndoye and Awono (2010) show that the revenues from the sale of these products are well above the guaranteed minimum wage in Cameroon (28216 XAF) and even higher than the salary of some public sector agents. Defo (2004) reported that the average income received by rattan collectors ranges from 87000 to 138000 XAF per year.

\section{What is the income from NTFPs for the State?}

Apart from tax revenues, the NTFPs' sector also contributes to State revenues through administrative procedures that imply costs for customers. These include expenditures for the recognition of the ability to conduct any forestry profession (Forestry license), administration fees linked to the application for permits giving the official right to access the resources (with specific quotas). The estimated cost for these annual fees is about 150,000 XAF per permit. In addition with the objective to control quotas attributed by the government, the owner is required to buy a counterfoil book of waybills justifying the origin and the quantity of the product conveyed to the market (200,000 XAF/book). Apart from the permit for NTFPs exploitation, there are other official documents that exporters should have, including (1) license for export, (2) certificate of origin of the product and (3) phytosanitary certificate and progressive and volume-based tax (COMIFAC 2008). In the assumption that all the expected taxes have been recovered by the government, the estimate of the contribution of the regeneration tax for about 12,000 tons of the cumulative volume obtained from the 16 NTFPs reported in this paper, regardless of self-consumption volumes is only 120.2 million XAF.

The State extracts minimal revenues in the formalization process of customers but an uncalculated amount of money is going downside the value chain via briberies (Ndoye and Awono 2010). Foundjem-Tita (2013) reported that a group of producers in the Southwest of Cameroon has mobilized about 1.3 million XAF to get accredited to exploit NTFPs legally. From this amount, the State has actually received only 600,000 XAF through a number of papers including stamps, social insurance and other administrative services. Other studies (GIZ/ProPSFE 2012, Mekongo 2011) claimed that a group of producers in eastern Cameroon had released 3 million XAF to get a group license for forestry services. Unlike Foundjem-Tita (2013), these studies did not indicate what proportion of the spending went to the State treasury. However, both studies show that not only compliance with administrative requirements to sell NTFPs can generate revenues for the State but also, as long as the system will remain complex and unclear, officials and non-officials will 
continue to harm the sector with governance concerns. Therefore, finance and taxation measures directly impact the use, management and trade of NTFPs, and the broader equity and sustainability of the sector (Laird et al. 2010).

\section{DISCUSSION}

The data has been used for only 16 vegetal NTFP in this paper. However taking into consideration the large number of NTFPs (Eyog et al. 2006), a strategy should be put in place to develop a rigorous methodology for quantifying and estimating the economic value of the most important NTFPs. Our analyses have presented evidence that there are top priority species including Dacroydes edulis, Irvingia sp., Gnetum spp. Ricinodendron heudelotii. The annual economic values obtained are almost similar to Ingram et al. (2012) for those NTFPs. All are playing a determining role both at local and national level. Presumably, greater attention should be put on these products with policies that encourage national, regional and international trade and also strategies to adding value through processing via the private sector.

Many households make a living by trading NTFPs, amongst which spices, gums, barks, wild fruits, kernels and leaves in urban areas. Some of these NTFPs have been developed and now provide enough income to forest communities because they can be sold on national, regional and international markets. The observed market expansion can be attributed to consistent efforts that have been put in place by the State, international and local NGOs, development and research partners, and economic operators to add value to the product chains through production increase, domestication, and post-harvest technologies including processing. Other interventions include improved market access through collective action and group sales FAO (2006).

The economic value of vegetal NTFPs in Cameroon has been underestimated as the self-consumption has not always been incorporated. Existing literature on NTFPs is often not extended to the national level, but focalized on some specific regions. Such limitation prevents the government from understanding the actual contribution of NTFPs to the national economy in terms of values of trade, taxes generated and the level of employment created by the sector. As a consequence, the lack of information on the economic value of NTFPs as a whole and the link with other forest uses mean that forest policy recommendations are not based on clear evidence. Added to this, traders must pay the waybills (paper showing the quantity of the product carried by the permit owner to the market) from those who receive the permit from the government, sometimes without having connections with the exploitation of the NTFPs as such (Awono 2002a, Ndoye et al. 2010). Thus, instead of selling the authorized NTFPs, the permit owners sub-contract with those who do not have the papers, receiving important commissions above the normal cost. Such practices prevent the real NTFPs exploiters from accessing the permit to act legally but continue to spend a lot of money to do their job, which is not equitable (Laid, 2010). As for the State loss, our assessment remains relevant even though apart from the regeneration tax, there are other miscellaneous sources of income paid to the State when it comes to fulfill the requirements for permit allocation. Betti (2007) found that the regeneration tax was not fully recovered by the administration. In fact, based on the quotas attributed from the government, the expected annual amount should be103 million XAF, of which 90 million XAF (87\%) were recovered. Comparing these figures with those obtained a decade earlier; there is an improvement because in 1999, only 15 million XAF (29\%) were collected out of 51 million XAF expected from 9 companies issued permits for 5,114 tons of NTFPs. This may be due to a lack of desire coupled with uncertainty on quotas attributed as nobody is aware of the availability without prior inventories.

In addition, NTFPs provide benefits to marginalised communities (Schreckenberg et al. 2006). Although women play a major role in harvesting and selling NTFPs they still have minimal access to serving in strategic and power positions (Laird et al. 2010). According to the same author, men often have the extended management rights and control over the resource. They come in the first line in terms of management of related income. For the trading segment, 95\% of traders are women (Awono et al. 2002a, Ingram et al. 2012). Tieguhong, (2009) reported that 70 percent of women living in rural areas exploit natural resources to feed their families. Close to two decades ago Ndoye et al. (1997/98) analyzing the market chain of 5 NTFPs from Cameroon towards the borders with Equatorial Guinea and Gabon found that out of the 1,100 traders involved, almost all were women. Eyebe et al. (1999) concluded that men are more involved when the business requires consistent financial capital. While $95 \%$ of retailers in Cameroon are women, they only represent $29 \%$ of the wholesalers. The analysis of the distribution of power among actors is important in the context of global economy because the consequences are likely to be dramatic on women. In such a context, if not oriented, the NTFPs' business can withdraw women from rewarded activities, losing their jobs, sidelining them or deteriorating their working conditions. At the same time Zeeshan et al. (2009) revels that plant materials account for more than $80 \%$ of the world population depends on plant-derived medicine for the first line of primary health care. It would be expected that the government and privates enterprises take strategic actions to take advantage of the potential of vegetal NTFPs. Eba'a Atyi et al. 2009) was already emphasizing that trade in NTFPs remains largely informal and is poorly monitored by forestry authorities.

\section{CONCLUSION AND RECOMMENDATIONS}

Determining the contribution of NTFPs in Cameroon's economy suggests a classification of the different categories deriving from vegetal to animal products as the concept is vast and complex. In this paper we have only considered vegetal NTFPs integrating cash and subsistence economy to obtain the financial value from markets analyses and the financial value deriving from the direct consumption in producer households. A major factor hindering the development of 
NTFP based enterprises in Cameroon has been both the lack of information on the social role of these products and the real economic benefits that could be derived from a more efficient valorization, including processing and marketing. Increasingly, the civil society with assistance from international development agencies in Cameroon collaborates with the government to implement land and forestry reforms to benefit more to vulnerable people (Awono et al. 2013). It can be expected that these actions would lead to appropriate reforms to facilitate access to resources and enhance the value chain increased benefits particularly for producers and State. Extrapolation of existing data has been done based on additional interviews of the actors for consistency which suggest the convergence of efforts to come up with a global dataset at the National Statistics to made the task less elaborated to come up with the economic value of vegetal NTFPs in Cameroun. That situation is not specific to Cameroon but suggests that efforts should be deployed in the different countries of COMIFAC to make statistics available for high priority NTFPs to support the decision making process on natural resource management in general and on vegetal NTFPs in particular.

New policies should lead to a clear separation between NTFPs from the wild and those planted (agroforests products) to avoid confusion on taxations (FAO 2010b). It is essential that such a vision should be supported by the different governments of Central Africa (COMIFAC 2008). The indications from de Jong et al. (2000) and Schreckenberg et al. (2006) that the income from NTFPs trade can only be sustained if, amongst other factors, the resource base is maintained through controlled harvesting or plantation production have been confirmed. This paper has also presented evidence that some NTFPs complement with agricultural, directly or indirectly, in terms of food security, especially during times when the food gap needs to be bridged. Complementarities can be more efficient with more processing efforts on fragile NTFPs to be available beyond the production season.

NTFPs are providing hundreds of thousands of job, from production to markets, knowing that people are opportunistic moving from one product to another depending on the season. Those accessible the whole year, like Gnetum spp. can be a great source of producers' incentive in the humid forest zone, a center of millions of people relying on forest products. However, given the extreme diversity of NTFPs, the State should target the highest demand NTFPs including Prunus africana, Dacroydes edulis, Irvingia sp., Gnetum spp. Ricinodendron heudelotii for a strategic development plan to insure market supplies and preserve the environment.

The central concern of this paper is: what is the economic value of vegetal NTFPs in Cameroon? On the basis of the results of the analysis of the 16 vegetal NTFPs selected, we can state that the financial value is about $0,2 \%$ of the broadest quantitative measure of the Cameroon's total economic activity. Better valued via governance enhancement and processing initiatives, this contribution may be improved. This result reinforces the findings of Laid et al. (2010) who have showed that the myriad of bureaucratic and financial obligations associated with permitting for NTFPs traded as commodities has presented significant challenges to the economic viability of NTFP sector. For instance the trade of Gnetum spp. in Cameroon is officially restricted to the official holders. As the real exploiters cannot access this permit, they are forced to purchase the quotas from the official owners to act legally (Ndoye and Awono 2010). In fact the stakeholders have limited options to change regulatory arrangements, except to work illegally (Tieguhong et al. 2015). However, this sector should be seen as an interesting niche as a substantial local processing is required, which should lead to additional employment and sustainable growth of small and medium enterprises in the sustainable NTFP trade in Central Africa in general (Awono et al 2013).

\section{ACKNOWELDGEMENT}

The valuable suggestions made by anonymous referees are gratefully acknowledged.

\section{REFERENCES}

ARNOLD, M. 2002. Identifying links between income and poverty. Paper presented at ECTF/IIED Forestry and poverty reduction workshop, Edinburgh, 13 June 2002.

AWONO, A., AKOMBI, A., OWONA, H. and BARREAU, E. 2015. REDD+ around Mount Cameroon, southwest region of Cameroon. In SILLS, E.O., STIBNIATI, S., A., DE SASSI, C., DUCHELLE, A.E., KWEKA, D.L., RESOSUDARMO, I.A.P. and SUNDERLIN, W.D. (eds). $R E D D+$ on the ground. Center for International Forestry Research. 188-203 pp.

AWONO, A., BARREAU, E. and OWONA, H. 2015. In SILLS, E.O., STIBNIATI, S., A., DE SASSI, C., DUCHELLE, A.E., KWEKA, D.L., RESOSUDARMO, I.A.P. and SUNDERLIN, W.D. (eds). REDD+ on the ground. Center for International Forestry Research. 203-223 pp.

AWONO, A., NGONO, D.L., NDOYE, O., TIEGUHONG, C.J., EYEBE, J.P. and TONYE, M.M. 2002a. Etude sur la commercialisation de quatre produits forestiers nonligneux dans la zone forestière du Cameroun: Gnetum spp. Ricinodendron heudelotii, Irvingia sp., Prunus africana. FAO, Yaoundé: $96 \mathrm{p}$.

AWONO, A., NDOYE, O., SCHRECKENBERG, K., TABUNA, H., ISSERI, F. and TEMPLE, L. 2002b. Production and marketing of safou (Dacryodes edulis) in Cameroon and internationally: Market development issues. Forests, Trees and Livelihoods 12: 125-147.

AWONO, A., MANIRAKIZA, D. and INGRAM, V., 2009a. Étude de base de la filière Ndo'o (Irvingia sp.) dans les provinces du Centre, du Sud et du littoral du Cameroun. Yaoundé, Cameroun, CIFOR.100 p.

AWONO, A., DJOUGUEP, A., ZAPFACK, L. and NDOYE, O. 2009b. The Potential of Irvingia gabonensis: Can it contribute to the improvement of the livelihoods of producers in Southern Cameroon? International Journal of Social Forestry 2(1): 67-85. 
AWONO, A., NDOYE, O. and PREECE, L. 2010. Empowering women's capacity for improved livelihoods in nontimber forest product trade in Cameroon. International Journal of Social Forestry 3(2): 151-163.

AWONO, A., INGRAM, V., SCHURE, J. and LEVANG, P. 2013. Guide for small and medium enterprises in the sustainable non-timber forest product trade in Central Africa. CIFOR, Bogor, Indonesia: 34 p.

AYUK, E.T., DUGUMA, B., FRANZEL, S., KENGUE, J., MOLLET, M., TIKI-MANGA, T. and ZEKENG, P. 1999. Uses, management and economic potential of Dacryodes edulis (Burseraceae) in the humid lowlands of Cameroon. Economic Botany 53(3): 292-301.

BELCHER, B. 2005. Forest Products Markets, Forest and Poverty Reduction. International Forestry Revieew 7(2): 82-89.

BETTI, J.L. 2007. Plan d'action/. Stratégie pour une meilleure collecte des données statistiques sur les Produits Forestiers Non Ligneux au Cameroun et recommandations pour les pays de la COMIFAC. COMIFAC. Yaoundé Cameroun. 180 pp.

COMIFAC, 2008. Sub-regional Guidelines on the Sustainable Management of NWFPs of Plant Origin in Central Africa, Yaoundé, $26 \mathrm{pp}$.

COSYNS, H., DEGRANDE, A., DE WULF, R., VAN DAMME, P., TCHOUNDJEU, Z. 2011. Can commercialization of NTFPs alleviate poverty? A case study of Ricinodendron heudelotii (Baill.) Pierre ex Pax kernel marketing in Cameroon. Agric Rural Dev Trop Subtrop 112: 45-56.

DE BEER, J.H. and MCDERMOTT, M. 1989. The Economic Value of Non-Timber Forest Products in South East Asia. The Netherlands Committee for IUCN, Amsterdam.

DEFO, L. 2004. Rattan exploitation in the Yaoundé region of Cameroon. In: SUNDERLAND, T. et NDOYE O. (éds) Forest products. Livelihoods and Conservation: Case studies of Non-Timber Forest Products Systems. Volume 2. Africa: 291-316.

DE JONG, W., CAMPBELL, B.M. and SCHRÖDER, J.M. 2000. Sustaining incomes from non-timber forest products: introduction and synthesis. International Tree Crops Journal 10: 267-275.

DJEUKAM, R. 2007. Le cadre législatif et réglementaire de l'utilisation des produits forestiers non ligneux au Cameroun. DOI 10.1007/s13280-012-0347-5.

EBA'A ATYI, R., DEVERS, D., DE WASSEIGE, C. and MAISELS, Fiona. 2009. State of the forests of Central Africa: Regional Synthesis. In: DE WASSEIGE C., DEVERS D., DE MARCKEN P., EBA'A ATYI R., NASI R. and MAYAUX P. (eds). The Forests of the Congo Basin - State of the Forest 2008. Luxembourg: Publications Office of the European Union, ISBN 978-92-79-13210-0, doi: $10.2788 / 32259$

EYOG MATIG, O., NDOYE, O., KENGUE, J. et AWONO, A. (eds) 2006. Les fruitiers forestiers comestibles $d u$ Cameroun. Cotonou, Benin: International Plant Genetic Resources. 204 p.
FOUNDJEM-TITA, D., TCHOUNDJEU, Z., SPEELMAN, S., D'HAESE, M., DEGRANDE, A., ASAAH, E. VAN HUYLENBROECK, G., VAN DAMME, P. and NDOYE. 2013. Policy and Legal Frameworks Governing Trees: Incentives or Disincentives for Smallholder Tree Planting Decisions in Cameroon? Small-scale Forestry 12: 489505.

FAO, 1996. Rome Declaration on World Food Security and World Food Summit Plan of Action. World Food Summit 13-17 November 1996. Rome.

FAO, 2010a. Global Forest Resources Assessment. Main report. FAO, Rome. (163). 343 pp.

FAO, 2010b. Rapport Consolidé des Ateliers Préliminaires Techniques de Consultation Régionale sur les Produits Forestiers Non-Ligneux (PFNL). FAO, Yaoundé. 72 pp.

GIZ/PROPSFE, 2012. Gestion durable des PFNL au Cameroun. Note de cadrage stratégie d'accompagnement ProPSFE. GIZ/ProPSFE, Yaounde.

INGRAM, V., SCHURE, J., TIEGUHONG, J.C., NDOYE, O., AWONO, A. and IPONGA, D.M. 2014: Gender implications of forest product value chains in the Congo basin. Forests, Trees and Livelihoods. DOI: 10.1080/ 14728028.2014.887610

INGRAM, V., NDOYE, O., IPONGA, D.M., TIEGUHONG, J.C. et NASI, R. 2012. Produit forestier non-ligneux: contribution aux économies nationales et stratégies pour développement durable. In: DE WASSEIGE, C., DE MARCKEN, P., BAYOL, N., HIOL HIOL, F. et MAYAUX, P., DESCLEE, B., NASI, R., BILLAND, A., DEFOURNY, P. et EBA'A ATYI, R. (eds) Les forêts du bassin du Congo-Etat des Forêts 2010. 137-154 pp.

INGRAM, V. and BONGERS, G. 2009. Valuation of Non-Timber Forest product Chains in the Congo Basin. A methodology for Valuation.CIFOR.Yaounde, Cameroon, FAO-CIFOR-SNV-World Agroforestry CentreCOMIFAC. 80 p.

LAIRD, S.A., INGRAM, V., AWONO, A., NDOYE, O., SUNDERLAND, T., LISINGE, E. and NKUINKEU R. 2010. Integrating customary and statutory systems: the struggle to develop a legal and policy framework for NTFPs in Cameroon. In: Laird, S.A., McLain, R.J. and Wynberg, R.P. (eds) Wild Product Governance: Finding Policies that Work for Non-Timber Forest Products. Earthscan, London. 53-70 pp.

LESCUYER, G. 2010. Importance économique des produits forestiers non ligneux dans quelques villages du SudCameroun. Bois et Forêts des Tropiques 304(2): 20-24.

LETOUZEY, R. 1968. Etude phytogéographique du Cameroun. In: Lechevalier, P. (ed.) 28 cartes et graph. Paris, France. 511 pp.

MEKONGO, F. 2011. Amélioration de la chaîne de valeur des produits forestiers non ligneux (PFNL) exploités par les organisations féminines. Le cas des communes des Mbang et Lomié, Départements de la Kadey et du Haut Nyong, Région de l'Est, Cameroun.GIZ, Yaounde.

NNAMA, A., AWONO, A. et ENDEZOUMOU, G.B. 2012 Impacts des activités d'exploitation des feuilles d'okok dans les ménages paysans de la Lekié au Sud Cameroun. CIFOR, Yaoundé Cameroun. 57 pp. 
NDAM, N. and TONYE, M. 2004. Chop, but no broke pot': the Case of Prunus africana on Mount Cameroon. In: SUNDERLAND, T. and NDOYE, O. (eds) Forest products, livelihoods and conservation: Case Studies of nontimber forest product systems. CIFOR, Bogor, Indonesia. Volume 2. Africa: 37-52.

NDOYE, O. and AWONO, A. 2010. Regulatory policies and Gnetum spp. trade in Cameroon: Overcoming constraints that reduce benefits and discourage sustainability. In: LAIRD, S.A., MCLAIN, R.J. and WYNBERG, R.P. (eds) Wild Product Governance: Finding policies that work for non-timber forest products. Earthscan, London. 71-76 pp.

NDOYE, O., RUIZ PEREZ, M. R and EYEBE, A. 1997/98. The markets of non-timber forest products in the humid forest zone of Cameroon. Rural Development Forestry Network.Paper22c.25 pp.

NJOMAHA, C. 2008. Etude socio-économique de la filière gomme arabique dans le Nord et l'Extrême-Nord Cameroun. Rapport final IRAD/CEDC-SNV, Maroua, Cameroun, $125 \mathrm{p}$.

NKEM, J., FOBISSIE, B.K., IDINOBA, M., SOMORIN, A.O., NDOYE, O. and AWONO, A. 2010. Shaping forest safety nets with markets: Adaptation to climate change under changing roles of tropical forest in the Congo Basin. Environmental Science \& Policy 13: 498-508.

PETERS, C.M., GENTRY, A.H. and MENDELSOHN, R.O. 1989. Valuation of an Amazonian rainforest. Nature 339: 655-656.

RUIZ-PEREZ, M., NDOYE, O. and EYEBE, A. 2000. La commercialisation des produits forestiers non-ligneux dans la zone de forêt humide du Cameroun. Arbres, Forêts et Communautés Rurales 19: 29-35.

SCHRECKENBERG, K., AWONO, A., DEGRANDE, A., MBOSSO, C., NDOYE, O. and TCHOUNDJEU, Z. 2006.
Domesticating indigenous fruit trees to reduce poverty. Forests, Trees and Livelihoods 16: 35-51.

TAHIR, B.A.E and GEBAUER, J. 2004. Non-Timber Forest Products: Opportunities and constraints for poverty reduction in the Nubai Mountains, South Kordofan, SudnaDeutscher Tropentage, 2004, Conference on international Agricultural Research for Development. Berlin, Deutschland.

TIEGUHONG, J.C., NKAMGNIA, E.M. 2012. Household dependence on forests around Lobeke National Park, Cameroon. International Forestry Review 14(2): 196-212.

TIEGUHONG, J.C. NDOYE, O. VANTOMME, P. ZWOLINSKI, J. et MASUCH J. 2009. S'adapter à la crise en Afrique centrale: un rôle accru pour les produits forestiers non ligneux. Unasylva 233(60): 49-54.

VAN DIJK J.F.W. 1999. An assessment of non-wood forest product resources for the development of sustainable commercial extraction. In SUNDERLAND, T.C.H., CLARK, L.E. and VANTOMME, P. (eds) Non-wood forest products of central Africa. Current research issues and prospects for conservation and development. FAO, Rome. 37-49 pp.

VAN NOORDWIJK, M., BIZARD, V., WANGPAKAPATTANAWONG, P., TATA, H.L., VILLAMOR, G.B. and LEIMONA, B. 2014. Trees cover transitions and food security in Southeast Asia. Global Food Security. "http:// dx.doi.org/10.1016/j.gfs.2014.10.005i"

WORLD BANK, 2012. Gender equality and development. World development report Washington, USA. 458 pp.

ZEESHAN, H.S., MISRA, V., SINGH, S., ARORA, G., SHARMA, S. and SHARMA, S. 2009. Current status of herbal drugs and their future perspectives. Biological Forum-An International Journal 1(1): 12-17. 